\title{
AKTIVITAS ANTIHIPERGLIKEMIA EKSTRAK KULIT DAN DAUN SURIAN (Toona sinensis) PADA TIKUS DIABETES (Sprague-dawley) YANG DIINDUKSI STREPTOZOTOCIN
}

\section{(Antihyperglycemic activity of surian [Toona sinensis] bark and leaf extracts on streptozotocin induced to diabetic rats [Sprague-dawley])}

\author{
Rori Theresia $^{1 *}$, Syamsul Falah ${ }^{1}$, Mega Safithri ${ }^{1}$ \\ ${ }^{1}$ Program Studi Biokimia, Fakultas Matematika dan Ilmu Pengetahuan Alam, Institut Pertanian Bogor, \\ Bogor 16680
}

\begin{abstract}
This study aimed to examine the antihyperglycemia activity of ethanol extract of $70 \%$ on surian bark and leaves on diabetic rats induced with streptozotocin based on body weight, and fasting blood glucose level. Consist of 28 rats are grouped into 7 groups namely normal, negative control, positive control which given glybenclamide with a dose of $3.22 \mathrm{mg} / \mathrm{kg} \mathrm{bw}$, bark extract with dose of $150 \mathrm{mg} / \mathrm{kg} \mathrm{bw}$, bark extract with a dose of $300 \mathrm{mg} / \mathrm{kg} \mathrm{bw}$, leaf extract with dose $150 \mathrm{mg} / \mathrm{kg} \mathrm{bw}$ and leaf extract with dose $300 \mathrm{mg} / \mathrm{kg} \mathrm{bw}$. Diabetogenic mechanisms was conducted with intraperitoneal injection of streptozotocin at dose of $50 \mathrm{mg} / \mathrm{kg} \mathrm{bw}$. This research was conducted experimentally using complete randomized design (RAL) to analyze the results obtained. Bark extract with a dose of $150 \mathrm{mg} / \mathrm{kg} \mathrm{bw}$ had a better antihyperglycemia activity compared to the other groups which was showed by the decrease of blood glucose level percentage of $72.83 \%$ and this group also had ability to maintain body weight was better than the other groups as well as stable feed consumption during research process.
\end{abstract}

Keywords: antihyperglycemia, blood glucose, diabetic, surian

\begin{abstract}
ABSTRAK
Penelitian ini bertujuan untuk menguji aktivitas antihiperglikemia ekstrak etanol $70 \%$ kulit dan daun surian pada tikus diabetes yang diinduksi streptozotocin berdasarkan bobot badan, dan kadar glukosa darah puasa. Tikus terdiri dari 28 ekor yang dikelompokkan menjadi 7 kelompok yaitu kelompok normal, kontrol negatif, kelompok kontrol positif yang diberikan glibenklamid dengan dosis $3,22 \mathrm{mg} /$ $\mathrm{kg} \mathrm{bb}$, kelompok ekstrak kulit dengan dosis $150 \mathrm{mg} / \mathrm{kg}$ bb, kelompok ekstrak kulit $300 \mathrm{mg} / \mathrm{kg}$ bb, kelompok ekstrak daun dengan dosis $150 \mathrm{mg} / \mathrm{kg}$ bb dan kelompok ekstrak daun dengan dosis $300 \mathrm{mg} /$ $\mathrm{kg} \mathrm{bb}$. Mekanisme diabetogenik dilakukan dengan menginjeksi streptozotocin secara intraperitoneal dengan dosis $50 \mathrm{mg} / \mathrm{kg}$ bb. Penelitian ini dilakukan secara eksperimental yang menggunakan rancangan acak lengkap (RAL) untuk menganalisis hasil yang diperoleh. Kelompok ekstrak kulit $150 \mathrm{mg} / \mathrm{kg}$ bb memiliki aktivitas antihiperglikemia yang lebih baik dibandingkan kelompok laiinya yang ditunjukan oleh persentase penurunan kadar glukosa darah sebesar 72,83\% dan kelompok ini memiliki kemampuan mempertahankan bobot badan leih baik dibandingkan kelompok ekstrak lainnya serta konsumsi pakan yang stabil selama proses penelitian.
\end{abstract}

Kata kunci: antihperglikemia, glukosa darah, diabetes, surian

\section{PENDAHULUAN}

Diabetes mellitus (DM) adalah gangguan metabolisme kronis yang ditandai dengan tingginya kadar gula darah (hiperglikemia), yang dihasilkan dari kurangnya insulin dalam tubuh atau kegagalan sel-sel tubuh untuk merespon sirkulasi insulin (MPHS 2010), sedangkan di Indonesia menurut riset kesehatan dasar (Riskesdas) 2013 yang memeriksa pada penduduk dengan usia $\geq 15$ tahun memperkirakan jumlah penderita diabetes sebesar 12.191.564 jiwa dengan rincian 30,4\%

$\overline{\text { "Korespondensi: Telp: }}+6281253394523$, Surel: roritheresia@yahoo.com 
terdiagnosis menderita diabetes dan 69,6\% tidak terdiagnosis (Kemenkes 2014).

Pengobatan secara menyeluruh mencakup pengaturan diet yang benar, olahraga yang teratur, kemudian dilanjutkan dengan pemberian obat antidiabetik baik yang bersifat oral maupun suntikan (BPOM 2009). Berdasarkan mekanisme kerjanya, Obat Hipoglikemik Oral $(\mathrm{OHO})$ dapat dibagi menjadi tiga golongan. Golongan yang pertama adalah obat-obat yang meningkatkan sekresi insulin, meliputi Obat Hipoglikemik Oral $(\mathrm{OHO})$ golongan sulfonilurea dan glinida (meglitinida dan turunan fenilalanin), golongan kedua adalah yang bersifat sensitiser insulin (obat-obat yang dapat meningkatkan sensitifitas sel terhadap insulin), meliputi obat-obat hipoglikemik golongan tiazilidindon, yang dapat meningkatkan sensitivitas insulin sehingga bisa mengatasi masalah resistensi insulin tanpa menyebabkan hipoglikemia, dan golongan ketiga inhibitor $\alpha$-glukosidase yang bekerja secara kompetitif menghambat kerja enzim $\alpha$-glukosidase dalam saluran cerna, sehingga menurunkan penyerapan glukosa (BPOM 2009).

Pengobatan OHO mempunyai beberapa efek samping yang harus diwaspadai diantaranya diare, pusing, sakit kepala, mual, muntah. Pada penggunaan kombinasi insulin dan sulfonilurea berat badan dapat meningkat dan penggunaan kombinasi metformin dan sulfonilurea atau glikazid tunggal dapat menyebabkan turunnya berat badan. Bila dosis tidak tepat atau diet terlalu ketat dapat menyebabkan pasien mengalami hipoglikemia.

Hipoglikemia adalah efek samping yang paling harus diwaspadai yang ditandai dengan munculnya gejala seperti pandangan kabur, keluar keringat dingin, gelisah, pusing, dan detak jantung bertambah cepat (BPOM 2010). Oleh karena itu, diperlukan pengobatan alternatif yang tidak menimbulkan efek samping yang membahayakan bagi tubuh. Salah satu pengobatan yang dapat digunakan untuk mencegah diabetes adalah dengan tanaman herbal salah satunya adalah surian.

Menurut (Dartini et al. 2016) Toona sinensis menunjukan senyawa fenolik yaitu flavonoid dan terpenoid. Hal ini juga didukung oleh penelitian (Monisa 2016) yang melakukan uji fitokimia pada daun dan batang surian menunjukan bahwa semua sampel yang diuji mengandung flavonoid, triterpenoid dan tanin.

Menurut Syaefudin (2016) senyawa fenolik mampu menangkal radikal bebas atau berperan sebagai antioksidan. Terdeteksinya flavonoid dan tanin diduga sebagai penyebab ekstrak memiliki aktivitas antioksidan.

Menurut Monisa (2016) senyawa tanin yang terkandung di dalam kulit dan daun surian mampu menghambat aktivitas enzim $\alpha$ glukosidase yang didukung oleh Dalimartha (2005) yang menyatakan Tanin mempunyai aktivitas hipoglikemik yaitu dengan meningkatkan glikogenesis sehingga mempunyai potensi sebagai agen antidiabetes.

Penelitian ini bertujuan untuk menguji aktivitas antihiperglikemik ekstrak kulit dan daun surian secara in vivo pada tikus dijadikan diabetes dan mengetahui dosis yang tepat untuk menurunkan kadar glukosa darah pada tikus diabetes dengan rumusan masalah pengujian secara in vitro menunjukan adanya senyawa antioksidan yang berpotensi untuk menurunkan kadar glukosa darah, sedangkan pengujian secara in vivo belum dilakukan sehingga diperlukan pengujian in vivo untuk mengetahui khasiat ekstrak etanol daun dan kulit surian yang berpotensi menurunkan kadar glukosa darah pada penderita diabetes mellitus.

Diharapkan penelitian ini dapat bermanfaat sebagai informasi ilmiah bahwa ekstrak kulit dan daun surian memiliki kemampuan sebagai antihiperglikemik dan membantu penderita diabetes mengendalikan glukosa darahnya. Penelitian ini juga memberikan nilai tambah tanaman herbal sebagai obat diabetes.

\section{METODE}

\section{Desain, tempat, dan waktu}

Desain yang digunakan dalam penelitian ini adalah eksperimental. Rancangan yang digunakan adalah rancangan acak lengkap (RAL). Penelitian ini dilaksanakan di laboratorium penelitian Biokimia IPB dan laboratorium hewan coba PT Bimana Indomedical pada bulan Desember 2016 - Juli 2017.

\section{Jumlah dan cara pengambilan sampel}

Jumlah sampel yang digunakan dalam penelitian ini sebanyak 28 ekor tikus Sprague dawley yang dihitung berdasarkan rumus Frederer yaitu $(\mathrm{t}-1)(\mathrm{n}-1) \geq 15$ dengan $\mathrm{t}$ adalah jumlah perlakuan dan $\mathrm{n}$ adalah jumlah ulangan (Ridwan 2013). Penelitian ini telah mendapatkan persetujuan dari komisi etik hewan PT Bimana Indomedical dengan nomor animal care and use committee (ACUC number) R.01-17-IR. 


\section{Bahan dan alat}

Bahan yang digunakan adalah kulit dan daun surian, pelarut ethanol $70 \%$, aquades, tikus Sprague-dawley, streptozotocin, glibenklamid, ransum, larutan BNF 10\%. Alat yang digunakan adalah oven, maserator, glukoDR Plus AGM3000, pisau scalpel, vakum, kaset tissue, cetakan, bunsen, freezer, gelas ukur, labu erlenmeyer.

\section{Tahapan penelitian}

Ekstraksi (Teffu 2015). Ekstraksi kulit dan daun surian memiliki dua tahapan yaitu persiapan dan ekstraksi. Tahap persiapan dilakukan dengan cara pengeringan dalam oven dengan suhu $40-50^{\circ} \mathrm{C}$ selama 4 hingga 5 hari. Sampel yang sudah kering kemudian digiling hingga berukuran 20-100 mesh yang berbentuk serpihan serbuk (kadar air $\leq 10 \%$ ). Maserasi sampel dilakukan dengan merendam sampel dalam pelarut Etanol $70 \%$ dengan perbandingan 1:10, proses ini dilakukan dalam maserator selama 3x24 jam. Kemudian ekstrak sampel tersebut didiamkan selama 24 jam, maserat yang didapat dipisahkan, dilakukan penggantian pelarut dan dilakukan pengulangan sebanyak 3 kali.

Rancangan percobaan. Percobaan dilakukan selama 2 minggu, untuk mencari dosis yang efektif dari ekstrak kulit dan daun surian yang terpilih. Tikus jantan dibagi secara acak ke dalam 7 kelompok perlakuan, dengan jumlah ulangan sebanyak 4 ekor per kelompok yang diperoleh berdasarkan rumus Federer yaitu (t-1) (n-1) $\geq$ 15 dengan $t$ adalah jumlah kelompok perlakuan dan $\mathrm{n}$ adalah jumlah ulangan (Ridwan 2013).

Kelompok I adalah kelompok normal yang hanya dicekok akuades selama percobaan (hari ke-0 sampai hari ke-14). Kelompok II adalah kontrol diabetes yang diinduksi dengan streptozotocin $50 \mathrm{mg} / \mathrm{kg}$ bb (Hasibuan 2016) dan dicekok akuades $2 \mathrm{ml}$ per hari $(\mathrm{KN})$. Kelompok III adalah kontrol positif yang diinduksi streptozotocin dan diberi obat antidiabetes glibenklamid dengan dosis 3,22 mg/kg bb. Kelompok IV (K150), V (K300), VI (D150), dan VII (D300) adalah kelompok ekstrak yang diinduksi streptozotocin dan dicekok dengan ekstrak kulit dan daun surian dengan pelarut alkohol 70\% dengan dosis 150 dan $300 \mathrm{mg} / \mathrm{kg}$ bb. Ekstrak kulit dan daun surian yang sebelumnya berbentuk serbuk dilarutkan dengan aquades hingga mencapai dosis yang diinginkan yaitu masingmasing $150 \mathrm{mg} / \mathrm{kg}$ bb dan $300 \mathrm{mg} / \mathrm{kg}$ bb.

Pengamatan berat badan dan jumlah ransum dilakukan pada hari ke- 0,2 , dan 16 . Tikus yang telah diinduksi dengan streptozotocin selama 48 jam digunakan untuk menguji ekstrak daun dan kulit surian. Pengambilan sampel darah dari vena ekor tikus dilakukan pada tikus yang dibiarkan puasa selama 6-8 jam. Alat yang digunakan untuk mengukur tingkat glukosa darah adalah glukometer (Miles Inc, USA). Pengukuran kadar glukosa tikus puasa dilakukan pada hari ke-0, 2, 9, dan 16 setelah injeksi Streptozotocin. Semua tikus diamati untuk berat badan dan konsumsi pakan pada hari ke-7,0,2, 9 dan 16. Menurut WHO, tikus dinyatakan diabetes jika kadar gula darah puasa $\geq$ $200 \mathrm{mg} / \mathrm{dl}$ (Hasibuan et al. 2016).

\section{Pengolahan dan analisis data (Mattjik 2006)}

Hasil yang didapatkan dianalisis dengan menggunakan rancangan acak lengkap (RAL). Model rancangan tersebut adalah:

$$
Y i j=\mu+\tau i+\varepsilon i j
$$

\section{Keterangan:}

$\mu=$ pengaruh rataan umum

$\tau \mathrm{i}=$ pengaruh rataan $\mathrm{ke}-\mathrm{i}, \mathrm{i}=1,2,3,4$

$\varepsilon i j=$ pengaruh galat perlakuan ke-i dan ulangan ke-j, $\mathrm{j}=1,2,3,4,5,6,7,8$

Yij = pengamatan perlakuan ke-i dan ulangan ke-j.

Data yang telah diperoleh dianalisis dengan ANOVA (analysis of variance) pada selang kepercayaan $95 \%$ dan taraf $\alpha 0,05$, uji lanjut yang digunakan adalah uji Duncan. Semua data dianalisis dengan program SPSS.

\section{HASIL DAN PEMBAHASAN}

\section{Bobot badan dan konsumsi pakan tikus}

Masa adaptasi dilakukan selama 7 hari (sebelum perlakuan). Pengukuran dilakukan pada semua kelompok (Tabel 1). Bobot badan semua kelompok selama masa adaptasi mengalami peningkatan yang signifikan pada tarafnyata $(p<0,05)$. Pada H0 semua kelompok kecuali kelompok normal diinjeksi dengan STZ hingga H2 (48 jam), selama 48 jam terjadi penurunan yang signifikan pada taraf nyata $(\mathrm{p}<0,05)$ pada semua kelompok kecuali kelompok normal yang mengalami penurunan bobot badan yang tidak signifikan.

Pemberian perlakuan dilakukan selama 14 hari pasca diabetes dari H2 hingga H16. Selama 14 hari bobot badan diukur sebanyak dua kali yaitu pada H9 dan H16. Kelompok normal mengalami peningkatan bobot badan pada hari ke-9 dan hari ke-16 namun tidak signifikan pada taraf 
Theresia dkk.

Tabel 1. Rerata bobot badan tikus selama proses percobaan

\begin{tabular}{|c|c|c|c|c|c|c|}
\hline \multirow{2}{*}{ Kelompok } & \multicolumn{5}{|c|}{ Rata-rata bobot badan (g) } & \multirow{2}{*}{$\begin{array}{l}\% \text { Penurunan } \\
\text { hari ke } 0-16\end{array}$} \\
\hline & Hari ke- $(-7)$ & Hari ke- 0 & Hari ke- 2 & Hari ke- 9 & Hari ke- 16 & \\
\hline Normal & $186,4 \pm 2,5^{(\mathrm{b}, \mathrm{c})}$ & $197,7 \pm 2,2^{\mathrm{a}}$ & $197,5 \pm 3,3^{\mathrm{a}}$ & $205,1 \pm 5,3^{\mathrm{a}, \mathrm{b}}$ & $210,3 \pm 7,2^{b}$ & $-6,4$ \\
\hline $\mathrm{KN}$ & $177,5 \pm 2,9^{(\mathrm{c}, \mathrm{d})}$ & $207,3 \pm 4,0^{\mathrm{d}}$ & $194,7 \pm 4,8^{c}$ & $180,6 \pm 1,1^{b}$ & $158,9 \pm 4,2^{\mathrm{a}}$ & 23 \\
\hline $\mathrm{KP}$ & $201,4 \pm 4,6^{(\mathrm{d})}$ & $211,7 \pm 4,6^{\mathrm{d}}$ & $196,9 \pm 4,2^{\mathrm{d}}$ & $176,1 \pm 6,9^{\mathrm{b}}$ & $157,1 \pm 7,0^{\mathrm{a}}$ & $25,8^{*}$ \\
\hline K150 & $175,8 \pm 6,5^{(a, b)}$ & $206,5 \pm 5,7^{\mathrm{c}}$ & $194,5 \pm 9,2^{\mathrm{b}, \mathrm{c}}$ & $180,3 \pm 11,7^{\mathrm{a}, \mathrm{b}}$ & $169,9 \pm 18,1^{\mathrm{a}}$ & 17,7 \\
\hline K300 & $168,0 \pm 4,9^{(a)}$ & $206,4 \pm 2,5^{\mathrm{d}}$ & $195,7 \pm 4,8^{\mathrm{c}}$ & $179,6 \pm 6,6^{\mathrm{b}}$ & $161,6 \pm 9,8^{\mathrm{a}}$ & $21,7^{*}$ \\
\hline D150 & $175,6 \pm 3,8^{(a, b)}$ & $210,6 \pm 6,4^{\mathrm{d}}$ & $194,4 \pm 8,4^{\mathrm{c}}$ & $179,0 \pm 10,3^{\mathrm{b}}$ & $157,3 \pm 9,0^{\mathrm{a}}$ & $25,3^{*}$ \\
\hline D300 & $188,9 \pm 13,7^{(\mathrm{c})}$ & $204,9 \pm 5,8^{c}$ & $194,1 \pm 0,9^{b, c}$ & $183,2 \pm 13,1^{b}$ & $157,8 \pm 10,5^{\mathrm{a}}$ & 23 \\
\hline
\end{tabular}

Keterangan:*Menunjukkan perubahan signifikan pada taraf nyata 95\% (p<0,05), tanda (-) menunjukkan peningkatan bobot badan, ${ }^{a}$ nilai ditampilkan dalam rata-rata kadar glukosa darah $(n=4) \pm S D$, angka yang diikuti huruf yang sama pada baris yang sama menunjukkan tidak berbeda nyata, ${ }^{*}$ huruf yang sama di dalam tanda () pada kolom yang sama menunjukkan tidak berberbeda nyata.

$(\mathrm{p}<0,05) . \mathrm{KN}, \mathrm{KP}, \mathrm{K} 300$, D150 dan D300 mengalami penurunan yang signifikan pada taraf nyata $(\mathrm{p}<0,05)$ di hari ke-9 dan 16. Sedangkan penurunan pada K150 pada hari ke-9 tidak signifikan pada taraf nyata $(\mathrm{p}<0,05)$ dibandingkan hari ke-2 dan penurunan pada hari ke-16 tidak signifikan pada taraf nyata $(\mathrm{p}<0,05)$ dibandingkan hari ke-9.

Selama 16 hari pasca injeksi STZ, kelompok normal mengalami peningkatan bobot badan sebesar $6,4 \%$. Sedangkan kelompok lainnya mengalami penurunan bobot badan. Kelompok K150 mengalami penurunan bobot badan sebesar $17,7 \%$. Penurunan kelompok ini terendah dibandingkan kelompok lainnya yang mengalami penurunan bobot badan lebih dari $20 \%$.

Konsumsi pakan juga dilakukan pada masa adaptasi (Tabel 2). Konsumsi pakan kelompok normal, K150, K300, D150, dan D300 mengalami peningkatan yang signifikan pada taraf nyata $(p<0,05)$. Sedangkan kelompok KN dan KP tidak mengalami peningkatan yang signifikan pada taraf nyata $(\mathrm{p}<0,05)$. Selama 48 jam pasca injeksi STZ (hari ke-2) penurunan konsumsi pakan pada semua kelompok tidak berbeda nyata pada taraf $(\mathrm{p}<0,05)$.

Pasca dinyatakan diabetes, selama proses perlakukan konsumsi pakan semua kelompok pada hari ke-9 mengalami penurunan yang tidak berbeda nyata $(p<0,05)$ dibandingkan hari ke-2, hal ini disebabkan oleh tikus yang selalu merasa lapar sebagai akibat dari diabetes sehingga untuk memenuhi kebutuhan energi tikus memerlukan konsumsi pakan yang lebih banyak sebagai sumber glukosa (YGDI 2012). Sedangkan pada hari ke-16, kelompok normal tidak mengalami penurunan yang signifikan dibandingkan hari ke-9, sebaliknya kelompok lainnya mengalami penurunan konsumsi pakan yang signifikan pada taraf nyata $(\mathrm{p}<0,05)$ dibandingkan hari ke-9.

Peningkatan bobot badan yang disertai dengan nafsu makan yang tinggi menunjukan tikus telah menyesuaikan diri dengan lingkungan

Tabel 2. Rata-rata konsumsi pakan tikus selama percobaan

\begin{tabular}{lccccc}
\hline \multirow{2}{*}{ Kelompok } & \multicolumn{5}{c}{ Konsumsi pakan $(\mathrm{g})$} \\
\cline { 2 - 6 } & Hari ke- (-7) & Hari ke- 0 & Hari ke- 2 & Hari ke- 9 & Hari ke- 16 \\
\hline Normal & $15,0 \pm 0,00^{\text {(c) }}$ & $16,0 \pm 0,00^{\mathrm{a}}$ & $16,0 \pm 0,00^{\mathrm{a}}$ & $16,3 \pm 0,50^{\mathrm{a}}$ & $16,3 \pm 0,50^{\mathrm{a}}$ \\
KN & $15,0 \pm 0,00^{\text {(c) }}$ & $15,8 \pm 0,50^{\mathrm{b}}$ & $15,8 \pm 0,50^{\mathrm{b}}$ & $15,5 \pm 0,58^{\mathrm{b}}$ & $13,3 \pm 0,50^{\mathrm{a}}$ \\
KP & $15,5 \pm 0,50^{\text {(c) }}$ & $16,3 \pm 0,50^{\mathrm{b}}$ & $16,3 \pm 0,50^{\mathrm{b}}$ & $15,8 \pm 0,50^{\mathrm{b}}$ & $13,3 \pm 0,95^{\mathrm{a}}$ \\
K150 & $13,3 \pm 0,50^{\text {(b) }}$ & $16,5 \pm 0,58^{\mathrm{b}}$ & $16,5 \pm 0,58^{\mathrm{b}}$ & $15,5 \pm 0,58^{\mathrm{b}}$ & $14,3 \pm 0,58^{\mathrm{a}}$ \\
K300 & $12,5 \pm 0,58^{\text {(b) }}$ & $15,5 \pm 0,58^{\mathrm{b}}$ & $15,5 \pm 0,58^{\mathrm{b}}$ & $15,5 \pm 0,58^{\mathrm{b}}$ & $13,8 \pm 0,50^{\mathrm{a}}$ \\
D150 & $13,3 \pm 0,50^{\text {(a) }}$ & $16,0 \pm 0,00^{\mathrm{b}}$ & $16,0 \pm 0,00^{\mathrm{b}}$ & $16,3 \pm 0,50^{\mathrm{b}}$ & $13,8 \pm 0,50^{\mathrm{a}}$ \\
D300 & $15,0 \pm 1,17^{\text {(c) }}$ & $16,3 \pm 0,51^{\mathrm{b}}$ & $16,0 \pm 0,54^{\mathrm{b}}$ & $15,5 \pm 0,61^{\mathrm{b}}$ & $13,5 \pm 1,10^{\mathrm{a}}$ \\
\hline
\end{tabular}

Keterangan : Nilai ditampilkan dalam rata-rata bobot badan $(n=4) \pm S D$, angka yang diikuti huruf yang sama pada baris yang sama menunjukan tidak beda nyata, *huruf yang sama di dalam tanda ( ) pada kolom yang sama menunjukkan tidak berberbeda nyata 
dan tidak mengalami stres. Stres oksidatif pada tikus diabetes disebabkan oleh kadar glukosa dalam darah tinggi (hiperglikemia) akan menyebabkan produksi radikal bebas meningkat yang dapat dipicu oleh faktor endogen maupun eksogen. Faktor pemicu endogen adalah genetik, usia, dan oksidasi fosforilasi, sedangkan faktor eksogen disebabkan oleh aktivitas berlebihan, kondisi patologis, asupan makanan yang tidak seimbang, polusi dan sinar ultraviolet (Suryowati 2015). Stres dapat mempengaruhi pola makan dimana tikus yang dalam keadaan stres dapat menurunkan konsumsi pakan yang berbanding lurus dengan penurunan bobot badan (Santoso \& Pramadi 2006).

Selama proses perlakuan, kelompok normal mengalami peningkatan bobot badan, kelompok negatif mengalami penurunan bobot badan, hal ini disebabkan oleh tikus dalam kondisi hiperglikemik yang menyebabkan peningkatan glikosilasi sehingga terjadi kelainan biokimia dan morfologi berkat struktur protein sehingga menyebabkan komplikasi diabetes seperti nefropati diabetik, neuropati, dan kardiomiopati (Shokeen et al. 2008) yang didukung oleh Hasibuan et al (2016) yang menyatakan induksi STZ $50 \mathrm{mg} / \mathrm{kg}$ bb pada tikus Sprague-dawley dapat mengakibatkan hiperglikemia yang menyebabkan penurunan bobot badan.

Kelompok kontrol positif (KP) yang diberikan glibenklamid mengalami penurunan bobot badan. Penurunan bobot badan ini disebabkan oleh ekskresi glukosa (Falah et al. 2010) melalui aktivasi sel $\alpha$ pankreas dan meningkatkan aktivitas glukagon, glukagon merangsang glikogenolisis untuk memenuhi kebutuhan glukosa sebagai sumber energi (Murray et al. 2009). Kelompok ekstrak K150 memiliki kemampuan mempertahankan bobot badan yang lebih baik dibandingkan kelompok ekstrak lainnya. Ini mengindika- sikan pemberian perlakuan selama 14 hari dapat menjaga stabilitas konsumsi pakan dan ekstrak dapat memperbaiki kondisi tikus diabetes (Hasibuan et al. 2016).

Konsumsi tikus kelompok selama masa adaptasi mengalami peningkatan. Hal ini mengindikasikan tikus telah menyesuaikan diri dengan lingkungan. Konsumsi pakan Kelompok normal cenderung stabil pada kisaran 16 gram. Berdasarkan kebutuhan energi, konsumsi pakan diberikan antara 5-10\% bobot badan atau 10-15 gram (Suckow 2006).

\section{Kadar glukosa darah}

Kadar glukosa darah puasa diukur pada hari ke-0, 2, 9, dan 16 (Tabel 3). Kadar glukosa pada hari ke-0 berada pada kisaran normal yaitu 81-102 mg/dl. Kadar glukosa semua kelompok berbeda nyata pada taraf $(\mathrm{p}<0,05)$ pada hari ke-2 dibandingkan dengan kelompok normal. Pada hari ke-9, kadar glukosa kelompok KN, KP, $\mathrm{K} 300$, D150, dan D300 berbeda nyata dengan kelompok normal pada taraf $(\mathrm{p}<0,05)$, sedangkan kelompok K150 tidak berbeda nyata dengan kelompok normal pada taraf $(p<0,05)$. Pada hari ke-16, kelompok ekstrak memiliki kadar glukosa yang berbeda nyata dengan kelompok kontrol positif pada taraf nyata $(\mathrm{p}<0,05)$.

Selama 14 hari pemberian ekstrak yang dimulai dari hari ke-2 hingga hari ke-16, kelompok ekstrak mengalami penurunan kadar glukosa tertinggi terdapat pada kelompok K150 dan D300 sebesar 72,83\% dan 70,61\% yang diikuti oleh kelompok K300 sebesar 61,63\%, dan D300 sebesar 46,6\%. Sedangkan kelompok KN dan KP juga mengalami penurunan, namun tidak sebesar kelompok ekstrak.

Pengukuran kadar glukosa pada hari ke-0 dilakukan untuk membuktikan bahwa tikus yang digunakan dalam keadaan normal lalu diinjeksi

Tabel 3. Kadar glukosa darah puasa (mg/dl) selama percobaan

\begin{tabular}{|c|c|c|c|c|c|}
\hline \multirow{2}{*}{ Kelompok } & \multicolumn{4}{|c|}{ Kadar glukosa darah puasa (mg/dl) } & \multirow{2}{*}{$\begin{array}{l}\% \text { Penurunan } \\
\text { Hari ke } 0-16\end{array}$} \\
\hline & Hari ke- 0 & Hari ke- 2 & Hari ke- 9 & Hari ke- 16 & \\
\hline Normal & $102,25 \pm 6,13^{\mathrm{d}}$ & $101,00 \pm 5,48^{\mathrm{a}}$ & $104,50 \pm 7,14^{\mathrm{a}}$ & $96,00 \pm 6,83^{a}$ & 4,95 \\
\hline $\mathrm{KN}$ & $86,50 \pm 5,74^{\mathrm{a}, \mathrm{b}}$ & $366,25 \pm 33,57^{b, c}$ & $278,25 \pm 94,32^{\mathrm{c}}$ & $312,25 \pm 32,54^{\mathrm{d}}$ & 14,74 \\
\hline KP & $89,00 \pm 1,41^{\mathrm{a}, \mathrm{d}}$ & $368,75 \pm 24,96^{\mathrm{b}}$ & $259,25 \pm 88,79^{c}$ & $253,00 \pm 110,67^{\mathrm{c}, \mathrm{d}}$ & 31,39 \\
\hline K150 & $98,75 \pm 6,18^{\mathrm{c}, \mathrm{d}}$ & $345,00 \pm 38,51^{\mathrm{b}}$ & $121,00 \pm 27,45^{\mathrm{a}, \mathrm{b}}$ & $93,75 \pm 24,19^{a}$ & $72,83^{*}$ \\
\hline K300 & $92,75 \pm 2,06^{\mathrm{b}, \mathrm{c}}$ & $398,75 \pm 40,49^{\mathrm{b}, \mathrm{c}}$ & $213,75 \pm 105,37^{b, c}$ & $153,00 \pm 61,24^{\mathrm{a}, \mathrm{b}}$ & $61,63^{*}$ \\
\hline D150 & $94,50 \pm 1,91^{\mathrm{b}, \mathrm{c}}$ & $408,25 \pm 55,29^{d}$ & $252,50 \pm 69,26^{c}$ & $120,00 \pm 31,16^{\mathrm{a}, \mathrm{b}}$ & $70,61^{*}$ \\
\hline D300 & $81,75 \pm 9,11^{\mathrm{a}}$ & $371,75 \pm 6,40^{\mathrm{b}, \mathrm{c}}$ & $306,50 \pm 37,49^{c}$ & $198,50 \pm 81,79^{b, c}$ & $46,60^{*}$ \\
\hline
\end{tabular}

${ }^{a}$ Nilai ditampilkan dalam rata-rata kadar glukosa darah $(n=4) \pm S D$, angka yang diikuti huruf yang sama pada kolom yang sama menunjukan tidak beda nyata, ${ }^{*}$ menunjukan perubahan signifikan pada taraf nyata $95 \%(\mathrm{p}<0,05)$. 
dengan streptozotocin (STZ) agar tikus mengalami diabetes mellitus (DM). Pemberian STZ pada hari ke-0 dilakukan secara intraperitoneal dengan dosis tunggal $50 \mathrm{mg} / \mathrm{kg}$ bb (Hussan et al. 2013) di dalam pelarut buffer sitrat $(\mathrm{pH} \mathrm{4,5)}$ yang disiapkan dalam keadaan fresh (Teoh et al. 2010). Pada hari ke-2 atau 48 jam pasca induksi STZ semua kelompok mengalami peningkatan kadar glukosa hingga $>300 \mathrm{mg} / \mathrm{dL}$. Peningkatan kadar glukosa menunjukan bahwa tikus telah mengalami DM setelah diinjeksi dengan STZ selama 48 jam. Menurut WHO, tikus dinyatakan diabetes jika kadar gula darah puasa $\geq 200 \mathrm{mg} / \mathrm{dL}$ (Hasibuan et al. 2016). Hari berikutnya diberikan perlakuan selam 14 hari yang diukur kadar glukosa pada hari ke-9 dan ke-16.

Kadar glukosa kelompok normal tidak mengalami perubahan yang berarti. Kadar gula darah puasa normal menurut Wolfensohn dan Lloyd (2013) berada di kisaran 50-135 mg/dL. Kadar glukosa tidak mengalami penurunan yang berarti yang disebabkan STZ menghambat siklus krebs sehingga produksi ATP di mitokondria menjadi terbatas dan menyebabkan pengurangan secara drastis nukleotida sel $\beta$ pankreas (Szkudelski et al. 2001). Penurunan yang terjadi pada kontrol positif disebabkan oleh pemberian glibenklamid yang merangsang eksositosis insulin sehingga meningkatkan pengambilan glukosa oleh sel (Murray et al. 2009).

Kadar glukosa K150 pada hari ke-9 mengalami penurunan hingga berada pada kisaran normal, hal ini mengindikasikan ekstrak K150 memiliki aktivitas antihiperglikemik yang tinggi. Kelompok ektrak lainnya juga mampu menurunkan hingga kadar normal namun tidak terlalu signifikan. Hari ke-16, kelompok K150, dan D150 mampu menurunkan hingga berada pada kisaran normal, sedangkan K300 dan D300 juga mampu menurunkan kadar glukosa, namun tidak sebesar K150 dan D150. Hal ini mengindikasikan selama 14 hari pemberian perlakuan kelompok ekstrak memiliki aktivitas antihiperglikemik.

Perbedaan aktivitas antihiperglikemik dipengaruhi dari kandungan senyawa bioaktif pada masing-masing ekstrak (Hasibuan et al. 2016). Adanya senyawa bioaktif dalam ekstrak yang mampu menurunkan kadar glukosa menunjukan bahwa senyawa bioaktif dapat merangsang sel $\beta$ pankreas dengan melepaskan sejumlah besar hormon insulin yang membawa glukosa ke sel (Hasibuan et al. 2016).

Menurut Monisa (2016), senyawa bioaktif yang terdapat di dalam daun dan kulit surian adalah tanin, flavonoid, saponin, dan triterpenoid yang memiliki aktivitas antidiabetes. Flavonoid mampu menghambat $\alpha$-glukosidase melalui ikatan hidroksilasi dan substitusi di cincin $\beta$ (Prameswari et al. 2014). Saponin bersifat hipolipidemik sehingga insulin berfungsi normal (Doughari 2012). Triterpenoid memiliki kemampuan menyerap glukosa dan sekresi insulin (Sunaryo et al. 2012; Rathore et al. 2014). Tanin memiliki aktivitas antioksidan dan menghambat kerja enzim (Firdausi et al. 2013). Menurut Suryowati et al. (2015) senyawa kimia $n$.Hexadecanoic acid $\left(\mathrm{C}_{16} \mathrm{H}_{32} \mathrm{O}_{2}\right)$ memiliki aktivitas biologis sebagai antioksidan serta senyawa Octadecadienoic acid berperan untuk melindungi sel $\beta$ pankreas.

\section{KESIMPULAN}

Dosis terbaik ekstrak etanol kulit dan daun surian yang dapat menurunkan kadar glukosa darah adalah $150 \mathrm{mg} / \mathrm{kg}$ bb masing-masing sebesar $72,83 \%$ dan $70,61 \%$ dan mampu mempertahankan bobot badan tikus sebesar $17,7 \%$ dan $25,3 \%$. Perlu penelitian lebih lanjut tentang komponen bioaktif daun Surian (Toona sinensis) dan mekanisme penurunan kadar glukosa dalam darah tikus diabetes induksi Streptozotocin.

\section{UCAPAN TERIMA KASIH}

Penulis mengucapkan terima kasih kepada PT Bimana Indomedical yang telah menyediakan tempat penelitian bagi peneliti.

\section{DAFTAR PUSTAKA}

[BPOM] Badan Pengawas Obat dan Makanan. 2009. Diabetes Mellitus. Informasi produk terapetik 19(1):1-12.

[BPOM] Badan Pengawas Obat dan Makanan. 2010. Antidiabetik Oral. Infopom XI(5):110.

Dartini, Nurdin H, Afrizal, Ekaprasada MT, Suciati D. 2016. Isolation and Characterization Flavonoid from The Bark of Toona Surian (Blume) Merr. J Chem Pharm Res 8(6):156-159.

Doughari JH. 2012. Phytochemicals: Extraction Methods, Basic Structures and Mode of Action as Potential Chemotherapeutic Agents, Phytochemicals-A Global Perspective of Their Role in Nutrition and Health. [Internet]. [diunduh 2016 Apr 16]. Tersedia pada: www.intechopen.com. 
Falah S, Safithri M, Katayama T, Suzuki T 2010. Hypoglycemic effect of Mahogany (Swietenia macrophylla King) bark extracts in alloxan-induced diabetic rats. Wood research journal 1(2):89-94.

Firdausi A, Siswoyo TA, Wiryadiputra S. 2013. Identifikasi tanaman potensial penghasil tanin-protein kompleks untuk penghambatan aktivitas $\alpha$-amylase kaitannya sebagai pestisida nabati. Pelita Perkebunan 29 (1):31-43.

Hasibuan MS, Yasni S, Bintang M, Ranti AS. 2016. Antihyperglicemic activity of Piper crocotum leaves and cinnamomum burmanii bark mixture extract in streptozotocin-induced diabetic rats. J math fund Sci 48(2):178-191.

Hussan, Nazilah N, Ramdzi M, Choon YS, Adibah N, Lin TS. 2013. Piper sarmentosum water extract attenuates diabetic complications in streptozotocin induced Sprague-dawley rats. Sains Malaysiana 42(11):1605-1612.

[KEMENKES RI] Kementerian Kesehatan Republik Indonesia. 2014. Situasi dan Analisis Diabetes. Jakarta: Kementerian Kesehatan.

Mattjik AA. 2006. Perancangan Percobaan dengan Aplikasi SAS dan Minitab. Bogor: Institut Pertanian Bogor.

[MPHS] Ministry of Public Health and Sanitation. 2010. National Clinical Guidelines for Management of Diabetes Mellitus. Republic Of Kenya: Ministry of Public Health and Sanitation.

Monisa. 2016. Jenis tanin, total tanin, dan aktivitas penghambatan $\alpha$-glukosidase dari ekstrak daun dan kulit batang Surian (Toona sinensis Merr). [Tesis]. Bogor: Institut Pertanian Bogor.

Murray RK, Granner DK, Rodwel VW. 2009. Biokimia Harper. Jakarta: EGC.

Prameswari OM, Widjanarko SB. 2014. Uji efek ekstrak air daun pandan wangi terhadap penurunan kadar glukosa darah dan hispatologi tikus diabetes mellitus. Jurnal Pangan dan agroindustri 2(2):16-27.

Rathore K, Singh VK, Jain P, Rao SP, Ahmed Z, Singh VD. 2014. In-vitro and in-vivo antidiapogenic, hypolipidemic and antidiabetic activity of Diospyros melanoxylon (Roxb). Journal of Ethnopharmacology 155(2014):1171-1176.
Ridwan E. 2013.Etika hewan percobaan dalam penelitian kesehatan. J Indon Med Assoc 63(3):112-116.

Santoso, Pramadi. 2006. Kecemasan dan pola makan. Anima, Indonesian Psychological Journal 22(1):74-85.

Shokeen, Anand P, Murali YK, Tandon V. 2008. Antidiabetic activity of $50 \%$ ethanolic extract of Ricinus communis and its purified fractions. Food Chem Tox 46(11):34583466.

Suckow. 2006. The Laboratory Rat. USA: American College of Laboratory.

Sunaryo H, Kusmardi, Trianingsih W. 2012. Uji aktivitas antidiabetes senyawa aktif dari fraksi kloroform herba ciplukan (Physalis angulata L.) terhadap penurunan kadar glukosa darah dan perbaikan sel langerhans pankreas pada mencit yang diinduksi aloksan. Farmasains 1(5):246-251

Suryowati T, Rimbawan, Damanik R, Bintang M, Handharyani E. 2015. Efek Ekstrak Daun Torbangun (Coleus amboinicus Lour) sebagai Antioksidan pada Hati Tikus Diabetes. Prosiding seminar ilmiah PBBMI : 63-68.

Suryowati T. 2015. Efek esktrak daun Torbangun (Coleius amboinicus Lour) terhadap stress oksidatif tikus diabetes. [Disertasi]. Bogor: Institut Pertanian Bogor.

Syaefudin. 2016. Stabilitas total fenolik, aktivitas antioksidan, dan aktivitas penghambatan $\alpha$-glukosidase pada minuman fungsional berbasis sirih merah (piper crocatum ruiz \& pav.). J Gizi Pangan 11(2):83-90.

Szkudelski. 2001. The mechanism of alloxan and streptozotocin action in B cells of the rat pancreas. Physiol Res 50(2001):53-546.

Teffu. 2015. Komponen kimia dan bioaktif akar bahan Gorgonian (Genus rumphella dan Hicksonella) dari pulau Raijua-Nusa tenggara timur. JPHPI 18(1):83-97.

Teoh, Latiff A, Das S. 2010. Histological changes in the kidneys of experimental diabetic rats fed with Momordica charantia (bitter gourd) extract. Rom J Morphol Embryol 51(1):91-95.

[YGDI] Yayasan Ginjal Diatrans Indonesia. 2012. Hidup dengan diabetes dan hemodialisis. Indonesia: Yayasan Ginjal Diatrans Indonesia

Wolfensohn S, Lloyd M. 2013. Handbook of Laboratory Animal Management and Wel- 
Theresia dkk.

fare Eight Edition. Oxford: Blackwell Science Ltd. 